\title{
Classicized Hijazi: imposition of the hamzah
}

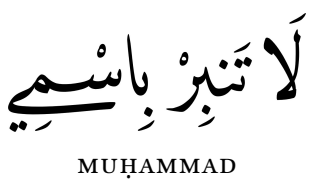

\subsection{Introduction}

In 202O, Ahmad Al-Jallad put forward the bold hypothesis that Classical Arabic as we know it today is not a single linguistic system but rather the outcome of a complex interaction between Old Hijazi, i.e. the language of the Quran and early Islamic Arabic on the one hand and the poetic register of the Qașīdahs of the MaSaddites on the other (Al-Jallad 2O2ob, $69 \mathrm{ff}$.). This suggestion is very much in line with what we have argued for so far in the previous chapters and previous studies (van Putten 2017a; 2017c; 2018; 2019b; van Putten and Stokes 2018).

While Quran today is read with a certain amount of linguistic variation, these reading traditions, despite their variation still agree on several central features such as the retention of the *? (in most environments), and a full case inflection with final short vowels and tanwin both of which appear to have been absent in the original form of Quranic Arabic as reflected by the QCT. To get from the language of the QCT to the language(s) used in recitation, this language has to have been 'classicized' over time. This claim will, of course, bring to mind the work of Karl Vollers (1906), who famously claimed that the Quran was composed in the Hijazi vernacular and only later reworked by the Arab grammarians towards Classical Arabic. His hypothesis was criticized by many, and few authors have taken his book particularly seriously but even fewer have seriously answered his arguments in a coherent way.

Vollers (1906, §39-43) considered the original Hijazi vernacular - and by extension the language of the Quran - to have lacked all forms of case inflection. This is not in keeping with the primary source material. First of all, the QCT very likely reached closure during the reign of Sutmān, around 650 CE (Sidky 
2021; Sinai 2014a; 2014b; van Putten 2019c). This is clearly before the development of grammatical theory, and reworking of the text by Arab grammarians towards a literary standard which gets established by the Arab grammarians over a century later is chronologically no longer defensible. Much of his argumentation requires us to assume that the consonantal text was changed in the decades after $650 \mathrm{CE}$. With this new material evidence, this part of his argumentation has lost most of its explanatory power. Likewise, evidence adduced from canonical and non-canonical readings alike only tells us something about the linguistic variation that was considered acceptable as part of the Sarabiyyah, and nothing about the language of the Quran itself as it is reflected in the QCT. The only argument that relies on the rhyme of the Quran is his argument for the absence of the indefinite accusative $(\S 42)$. He suggests that the indefinite accusative ending was invisible to rhyme, but this is clearly not the case and the presence of this vowel is in fact essential for the choice between certain

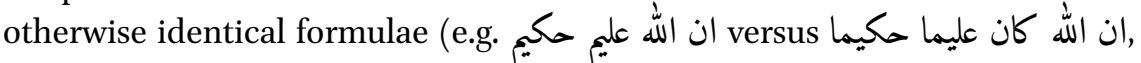
see van Putten and Stokes 2018, 145 f.). Any expression of case that is explicitly present in the QCT is certainly part of the language that the QCT was written down in, and likely (and sometimes demonstrably so) present in the language of the original composition as evidenced by the rhyme.

However, those arguing against Vollers have frequently taken the argument to the opposite extreme: any sign of any case at all must mean that Quranic Arabic had full case inflection exactly how the Arab grammarians present it, with full case/mood inflection and tanwin. But this conclusion is not borne out by the evidence either. Between a stage of full case inflection, which must certainly be reconstructed for Proto-Arabic (Al-Jallad and Putten 2017), and no case at all, there must be a whole spectrum of case systems that were in the process of losing it. Already in the pre-Islamic period there were clearly varieties that had lost their case inflection to various degrees.

While the loss of case and mood has often been seen as a catastrophic event that very rapidly, or instantly changed the language from its Old Arabic stages to its Neo-Arabic stage (e.g. Ferguson 1959; Blau 1977; Versteegh 1984), discoveries of the past decades in Arabic dialectology and especially of recent years in Old Arabic epigraphy have made it clear that such a simplified scenario cannot account for the variation that we see. Safaitic, for example, seems to have only marked the accusative case, while not marking tanwin at all, centuries before the rise of Islam (Al-Jallad 2015, 69). Also, the case system of Nabataean Arabic, lacks tanwin in the earliest period but still seems to have a tripartite case inflection. Only later this case distinction seems to be lost, exchanged with an invariable $\langle-w\rangle$ ("wawation") - a trace of the original nominative (Al-Jallad forthcoming; Diem 1973). Likewise, the case system present in the Damascus 
psalm fragment is almost completely on its way out, despite being written around the same time as the activities of the early Arab grammarians (Al-Jallad $2020 \mathrm{~b})$. However, if we would follow the indications of the Arab grammarians, we would never know such varieties existed at all, as these clearly fell outside of their normative framework of proper Arabic.

It is now clear that certain forms of pre-Islamic Arabic with clearly archaic features-often more archaic than what we find in Classical Arabic-existed which, nevertheless had a different and frequently more reduced ?ifräb/tanwin system than Classical Arabic. It is therefore not a given that this system, whose linguistic reality is proven by the rhyme and meter in pre-Islamic poetry, could be imposed onto the language of the Quran, even if it is present in all the Quranic reading traditions.

Van Putten \& Stokes (2018) argued that the Quran did not completely lack the Proto-Arabic case system as Vollers suggests, but rather had a transitional system where final short vowels and nunation had been lost (where an had become $\bar{a}$ ). Case expressed by long vowels was generally retained, as well as case vowels for nouns in construct. In other words, we have argued and adduced evidence that case was only retained in places where the QCT actually reflects it. Examples usually invoked to prove that the case system must have operated, tend to not counter such a system particularly well. In countering Vollers' suggestion, for example Fück (1950, 2) cites the following examples which he considered ambiguous had case been lost. All of the examples would be unambiguous in the case system that Van Putten \& Stokes reconstruct. The examples of Fück are given below along with the likely form they may have taken in Quranic Arabic as I would reconstruct it:

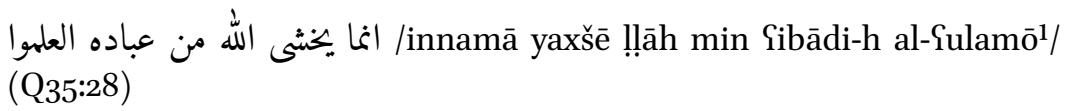

'Only the knowledgeable among his servants fear God'

/wa-idāạ ḥậar al-qismah ulū l-qurbē/ (Q4:8)

'And when relatives, at the time of division, are present'

1 The interpretation of the final $w \bar{a} w$-Palif sequence in what in Classical Arabic is pronounced al-\{ulamā?u remains somewhat difficult to determine. It seems fairly clear that it does not represent $\bar{a} w u$ or $\bar{a} w . \bar{o}$ seems like a reasonable option. See Appendix A.2.3.6 for a discussion. 
anna ḷāh bariyy min al-mušrikīna wa-rasūlu-h/ (Q9:3)

'That God is free from the idolaters, as is his messenger'

واذ ابتلى ابرهم ربه

'And when his lord tried Abraham'

The first two of these are in fact distinguished by the rasm, and certainly did not present any problem to the understanding. The other two would not be ambiguous if, as we have argued, case vowels had been retained in construct. One should note, however, that even if such phrases would be fully ambiguous, pragmatically such phrases hardly ever pose true ambiguity - it is unlikely that anyone would think that it is God who fears the servant in Q35:28, for example. The very fact that Classical Arabic writing manages to communicate the intended meanings with a writing system that generally does not express case, should make it clear that such ambiguities can be resolved to a large extent through pragmatic considerations.

Moreover, many extra-linguistic hints such as intonation and pause, which are likely to have played a role in the original composition of the Quran, are systematically erased almost completely in Quranic recitation. These too would have helped with the resolution of ambiguities, even with a strongly reduced case system. It is therefore difficult to accept unusual word order to hold much weight as an argument for a full case system, and evidence for its presence or absence needs to be found elsewhere.

Starting from the linguistic situation where *? and final short vowels and nunation were lost completely, one would naturally expect that at times the Quran had been imperfectly classicized towards a variety that did have these features. It has, on multiple occasions, been claimed that the Quran cannot have been classicized for the exact reason that there are no such traces of imperfect classicization, as exemplified, for example by Blau saying that "the total lack of Neoarabic and pseudo-correct features in the Koran establishes a linguistic situation in which the differences between the literary and spoken language could not have been too far-reaching" (Blau 1977, 15). I agree with Blau that the Arabic of the Quran was probably close to the vernacular of the Hijaz, and that little to no reworking has been undertaken on the consonantal text. However, this implies that the language of the Quran did not have hamzah, and indeed that it had a reduced case/tanwin system. Blau seems to admit the possibility that Quranic Arabic had a somewhat reduced system that had lost (at 
least) word final $-i$ (pg. 15 f.), but does not commit to a strong opinion on what this system may have looked like.

However, we frequently find evidence in the Quranic reading traditions that these texts have been grammatically reworked by its reciters. Pseudo-correct features that clearly point to conscious and artificial tampering with the language of recitation frequently appears in them. In fact, Vollers found many examples of this in his magnum opus, although many of his critics seem to have missed these points, and have rather chosen to attack his admittedly much weaker argumentation in favour of his 'caseless Quran'.

As I see it, there are three main systematic features that differentiate Quranic Arabic as it can be reconstructed from the QCT, and how it appears in the Quranic reading traditions. The first, and the most widely admitted difference is that Quranic Arabic seems to have lost the hamzah entirely, something that is obvious from the orthography and can be clearly demonstrated from Quranic rhyme (van Putten 2018). In this chapter we will show that the pattern of both the pseudocorrect presence and absence of hamzah frequently occurs in the Quranic readings, clearly showing that later philologists have inserted the hamzah into the recitation of the Quran and were not always successful in doing so with regard to the placement that would be expected from its etymology.

The second feature, is the quintessentially Classical Arabic feature, namely the system of PiSräb and tanwin, which the language of the QCT appears to have largely lost (van Putten and Stokes 2018). In chapter 7, I will show that to the Quranic reciters, placement of Pi $i \overline{r a} b$ and tanwin was a highly theoretical undertaking, not one that unambiguously stemmed from its prototypical recitation and composition. Within this theoretical framework, there are also occasional cases where the reciters fail to fully apply the final short vowels in a manner that would be expected, yielding forms without final short vowels, where we would have expected them.

The third feature, is the retention of a phonemic distinction between the two Palif maqșūrahs, the one written with ?alif reflecting /ā/ and the one written with $y \bar{a}$ ? reflecting $/ \overline{\mathrm{e}} /$, a distinction clearly reflected in the Quranic rhyme (van Putten 2017a). This feature is different from the previous two. While all readings have, to a greater or lesser extent, retained a good number of cases of etymological hamzah, and all of them in principle reflect the Classical Arabic system with Pi $i \overline{r a} b$ and tanwin, this last feature is a topic of disagreement among the canonical readers. While normative Classical Arabic eventually opts for a merger of these two sounds, the Quranic reading traditions give ample evidence for an original distinction between the two sounds. This is found regularly in the readings of Ḥamzah, al-Kisā?ī, Xalaf and Warš Yan Nāfí. It is self-evident that not 
both retention and loss can be true simultaneously for the original composition of the Quran, and rhyme clearly favours the readings that retain this distinction. I will therefore not discuss this feature in more detail in these chapters.

\subsection{Pseudocorrect Hamzah}

In $\S 5.2$ and Van Putten (2018) we have argued that the language of the QCT lacked a hamzah altogether and that the reading traditions eventually classicized Quranic Arabic. Van Putten (2018, 98-101) showed already that the reading traditions treat the hamzah rather inconsistently. In phonetically identical environments sometimes the hamzah is lost while other times it is not, occasionally based on grammatical principles, other times seemingly by rhyme. The fact that the Quranic readings fail to undergo regular sound changes clearly suggests that the readings are not natural language, but rather a mixed literary register (see §3.3).

Evidence for a transition from a Hijazi hamzah-less pronunciation of the Quran, as confirmed by the rhyme and orthography, towards a more classical system can be seen by the presence of pseudocorrection of the hamzah in the Quranic reading traditions. Indeed, we would expect to see the application of hamzah where it should have never appeared etymologically, and likewise failure to insert the hamzah where we would etymologically expect it. Cases of both types of pseudocrrection can indeed be found in the reading traditions (as well as in Classical Arabic). This is a strong indication that Quranic Arabic originally lacked the hamzah and that it was only later artificially inserted, as it became fashionable for proper Arabic to have a hamzah.

There appears to be a historical memory of this transition taking place in the beginning of the second Islamic century, at least for Medina, as Ibn Muğāhid (6o) reports that Qālūn said: kāna ?ahlu l-madīnati lā yahmizūna ḥattā hamaza bnu ğundabin, fa-hamazü mustahzi?üna, wa-stahzi? "The people from Madīnah used to not apply the hamzah until [Muslim] Ibn Ğundab (d. 130 AH/747 AH) applied the hamzah. From then on they applied the hamzah to mustahzi?üna and istahzi?"2

2 See also al-Dahabī (I, 59); Ibn al-Ǧazarī (al-Ġāyah, II, 26o). 


\subsection{Hamzah among the Quranic Readers}

Before we discuss the cases of pseudocorrect hamzah it is worth discussing the generalizable treatment of the hamzah in the different canonical reading traditions, as this way we are better able to appreciate the instances when readers deviate not just from the imagined classical Arabic norm, but also from their own norms.

The majority of the Quranic readers regularly retain the hamzah in most environments. Readers such as Yāṣim, Ibn Dakwān San ibn Yāmir, Qālūn Yan Nāfị, Ibn Katīir, al-Kisā?ī, Xalaf and YaYqūb by and large retain the hamzah in all positions. That is: in pre-consonantal position, post-consonantal position and in intervocalic positions. The only position where all readers agree that etymological hamzah is to be dropped is in sequences of two hamzahs, where the first one is followed by a vowel and the second by a consonant, within a single word, e.g. ?a?muru-hū $\rightarrow$ ?āmuru-hü 'I order him' (Q12:32).

The remaining readers adhere to several general principles of the dropping of the hamzah. In the following discussion we will only discuss cases of pseudocorrect hamzah that cannot be explained by the general rules of the readings.

Pabū ĞaSfar drops each pre-consonantal hamzah, with compensatory lengthening, e.g. mu?minūna $\rightarrow$ müminūna, šìt $a \rightarrow$ šita, ya?kulu $\rightarrow$ yākulu. He likewise does the same for word-final vowel + ? sequences: iqra? $\rightarrow$ iqrā, nabbi $\rightarrow \rightarrow$ $n a b b \bar{\imath}$ (Ibn al-Ğazarī, §1466). Besides this he also regularly shifts the sequences

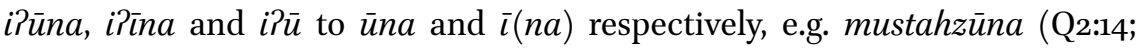
Q15:95), Pa-tunabbūna (Q10:18), muttakūna (Q36:56), fa-mātūna (Q37:66; Q56: 53), al-munšūna (Q56:72), al-xāțūna (Q69:37), al-xāțīna (Q12:29, 91, 97), almustahzina (Q15:95), muttakina (Q18:31), yutfü (Q9:32). He has a single exception to this: xāsiłīna (Q2:65; Q7:166) (Ibn al-Ğazarī, §1496). He would also drop the hamzah whenever it stood in the sequence $u$ ? $a$, where $?$ was the first root

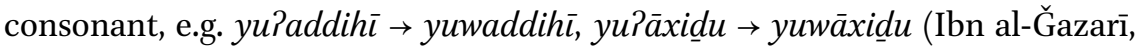
$\S 1485)$.

Pabu Yamr has the option to drop prescononsantal hamzah, or to conservatively keep it (Ibn al-Ğazarī, §1472-1474). However, even with the option to drop the hamzah, Pabu Yamr would not drop it if hamzah was root-final, and in the apocopate or imperative. This is not just in word-final position such as naša? and tasu?, but also on morpheme boundaries such as ?anbi?-hum and ?arği?$h u$, where the hamzah is pre-consonantal within the same word (Ibn al-Ǧazarī, $\S 1475)$.

Warš Can Nāfí has two main treatments. In the transmission path of alPazraq the rule is that Warš drops pre-consonantal and intervocalic hamzah, 
but only if it is the first root consonant. Hence: mu?minun $\rightarrow$ müminun and $y a ? x i \underline{d} u \rightarrow y \bar{a} x i \underline{d} u$, and yu?axxiru $\rightarrow$ yuwaxxiru but not bi?sa, ği?ta, or yaša? (Ibn al-Ǧazarī, §1471).

The other path of transmission of Warš, that of al-Paṣbahānī, has a principle that is closer to that of ?abū Ğaffar. He drops any preconsonantal hamzah, regardless of the position in the root. He, however, has a list of exceptions to this general rule, causing him to retain significantly more hamzahs than Pabu Ğaffar. These exceptions are: ba?s, ba?sā? , (al)-lu?lu?, riłyan, ka?s, ar-ra?s, ğiitta (and other forms of the verb such as ğiinā-hum), nabbi? (and other apocopates derive from that root), qaraita (and other suffixed forms of the verb); hayyi?/yuhayyi? and tu?wī/tu? 'wi-hi (Ibn al-Ǧazarī, §1469). Like Warš in the path of al-Pazraq, he also drops any word-internal intervocalic hamzah when it is the first root consonant (Ibn al-Ğazarī, § 1485).

Both transmissions of Warš are in agreement that post-consonantal hamzah is dropped if there is a word boundary between the word-final consonant and the next word, or if the word preceding the hamzah is the definite article. Thus, qad Paflaha $\rightarrow$ qadaflaḥa and al-Parḍu $\rightarrow$ alarḍu (Ibn al-Ğazarī, §1541).

Ḥamzah and Hišām San ibn Yāmir both have conservative hamzah treatment, but make a special exception in pause. Hišām drops all word final hamzahs in pause (after dropping the final short vowels), whereas Hamzah drops all hamzahs in pause. That is, words like ya?kulu, yas?alu, al-lu?lu?i, assamā?u and al-Pardu would be pronounces yākul, yasal, as-samā, ${ }^{3}$ al-lülū and alarḍ in pause (Ibn al-Ğazarī, §1541).

\subsection{Pseudocorrect Presence of Hamzah}

In several cases throughout the Quran, we find examples where readers have a hamzah where clearly none was ever present etymologically. Such pseudocorrections fall into three types. First, some words can be shown to behave irregularly within the system of the Sarabiyyah in the appearance of the hamzah. Second, some words are loanwords from Hebrew or Aramaic where the hamzah is absent, but has been inserted into the Arabic form. Finally, there are several inherited Semitic words which on comparative Semitic grounds can be shown to have never had a hamzah in their stem but have acquired them in the readings.

3 Optionally with an overlong vowel triggered by the following, now dropped hamzah, or without the length. 


\subsubsection{Diyā? $\rightarrow$ dị $\bar{a}$ ?}

Qunbul Yan Ibn Katîr pronounces the verbal noun of $d \bar{a} ? a(\sqrt{d} w$ ? $)$ not as diyyā?, as one would expect for a fi $\uparrow \bar{a} l$ pattern of such a root, but as dị? $\bar{a}$ ? (Ibn al-Ğazarī $\S 1534$ ). This is clearly pseudocorrect: the root consonant $w$ (which appears in the also Quranic daw?) is simply expected to shift to $y$ after $i$ (for example II$w$ roots with CiCāC plural like, diyār 'dwellings', or verbal nouns like qiyāmah 'resurrection'). ${ }^{4}$

Ibn Muğāhid (323), who was a direct student of Qunbul, was clearly bothered by this reading. He reports that Ibn Katiin read it as such and that that is how he learned it from Qunbul. However, he brings transmissions of not just alBazzī, one of the transmitters he also reports in his discussion of his ?isnāds of Ibn Katiîr but also Ibn Fulayh, that they rejected the reading and that Ibn Katiir only read with one hamzah. He discusses this word again at Q28:71, where Ibn Muğāhid (495) says: "Only Ibn Kātīir read bi-dîāâin with two hamzahs. And I learned it thus from Qunbul, but he was wrong (galața)."

\subsubsection{Mūṣadah $\rightarrow$ mu?șadah}

The C-stem passive participle written as oوصده 'closed' (Q90:20; Q104:8) is read by the majority of the readers as mūṣadah. However, Hafṣ Yan Yāșim, Rabū Yamr and Ḥamzah read it as mu?șadah (Ibn al-Ğazarī, §1484). This variant is a clear pseudocorrection. The verb ?awșada 'to close' ( $\sqrt{\text { wṣd }}$ ) is also recorded as ?āṣada ( $\sqrt{ }$ șd) in classical lexicons, but within the QCT the verb clearly has $\sqrt{ }$ wṣd as its root, as is confirmed by wașid 'threshold, doorstep' derived from the same root

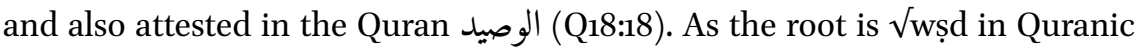
Arabic, müșadah is the expected form and mu?șadah the pseudocorrection resulting from the ambiguity of the hamzah-less Quranic Arabic, where C-stem participles (and imperfect) of I-? regularly merge with I-w roots.

This pseudocorrection did not go unnoticed by classical authors either. AlZamaxšarī (d. $538 \mathrm{AH} / 1144 \mathrm{CE})$ in his al-Kaššăf $(\mathrm{IV}, 257)$ brings a report (without Pisnād) on the authority of ŠuSbah—who read mūssadah — saying: "our Imam [i.e. Yāșim] would apply the hamzah to موصده; and I wanted to plug my ears whenever I would hear it." This story may be apocryphal, designed to explain the difference between Hafṣ and ŠuSbah in their transmission of Yāṣim. Nevertheless, it highlights that clearly this reading was disturbing enough to the grammarian and theologian al-Zamaxšarī, that it was worth relating it.

4 Vollers $(1906,95)$ sees the hamzah as the transitional stage between an original ${ }^{*} d i w \bar{a} ?$ and the form diya $\bar{a}$. There is no reason to assume nor is there evidence that such a transitional stage took place.

5 This line is missing in the first edition of this text, but the third edition has this line added. 
The confusion between I-? and I-w roots is well-known for the D-, L- and C-stems in Middle Arabic (Blau 1967, $\S 72.1$ ), and is the result of subsequent analogies after the loss of the hamzah, which is common to Quranic Arabic and Middle Arabic alike. This results in a merger of the two root types in the prefix conjugation and participial derivations. This leads to the frequent appearance of pairs of I-P and I-w verbs with identical meaning. We find a similar case of such a development for توكيدها 'their affirmation' (Q16:91), which looks like the verbal noun of wakkada 'to affirm', but Classical Arabic lexicons also record ta?kid and rakkada with the same meaning. When cognates in other Semitic languages are lacking, it is often difficult to recover whether the I-? form was originally a pseudocorrection, or that the I- $w$ is simply a generalized form from an original I-P verb in a dialect that has lost the hamzah.

\subsubsection{DiPzā}

Another case of pseudocorrection in Ibn Katīir's reading is the word ضيز 'most

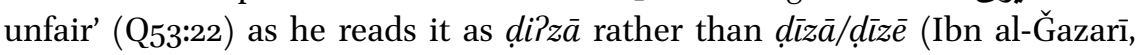
$\S 1484$ ). While this word seems to be basically only known to the Arabic lexicographers and grammarians from its Quranic context, its morphology is transparent: it must be a feminine elative, as there are no other feminine adjectives that end in Palif maqșürah. It being an elative, one would expect the pattern to be $\mathrm{CuCC}$, had the noun indeed been derived from a root $\sqrt{\mathrm{d}} \mathrm{Pz}$, then we would expect $d u P z \bar{a}$, not $d i p z \bar{a}$, which rather is a pseudocorrect insertion of hamzah

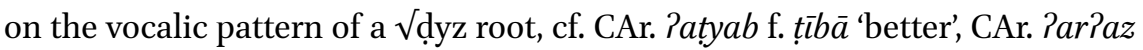
f. ru?zā 'more roaring.'

\subsubsection{Manōh $\rightarrow$ manāiah}

The majority of the readers read the name of the pre-Islamic goddess Manāt as manāh. But Ibn Katīir reads this as manā?ah. The goddess Manāt is a personification of Fate, whose name is deribed from the root $\sqrt{\mathrm{mnw}}$ alternating with $\sqrt{\text { mnyy }}$ This root is well-attested in Pre-Islamic Arabic, the deity Manāt is spelled mnwt in Nabataean, and the fates are also an often invoked in Safaitic as mny /manāy/ (Al-Jallad and Jaworska 2019). The insertion of the hamzah by Ibn Katīir cannot be seen as anything but a pseudocorrect reading.

6 Arabic lexicographers appear to have been aware of the weakness of this reading, as, for example Lisān (2540c) lists $\underline{d u} \bar{\imath} z \bar{a}$ first, then $d \bar{u} z \bar{a}$ (the expected form if one would drop the hamzah) and only then $\operatorname{di}_{i} z \bar{a}$ and $\operatorname{diz} \bar{a}$ respectively. 


\subsubsection{Sādan l-?ūlā}

Q53:50 contains a unique sequence in the Quran, the only place where a word ending in tanwin is followed by the definite article, which is followed by a word that starts with a hamzah. This sequence yields a cluster of three consonants / Yādan l-Pūlā/, which is resolved differently by different readers (Ibn al-Ǧazarī, $\$ 1547-1557 \mathrm{~s})$. Normally, in the case of a clash of nunation with the definite article, an epenthetic $i$ is inserted, and that is the reading of the majority of the canonical readers: [ [Yādani l-P̄ūlā]. Warš Yan Nāfi and Tabū Yamr, however, resolve this cluster differently in this specific case. The tanwin is assimilated to the läm and the subsequence /ll?/ is resolved by eliding the glottal stop of the word, yielding [Yādal-l-ūlä] .

Qālūn Yan Nāfi however, applies yet another development and reads the [Yādal-l-u?lā]. Qālūn must have interpreted the feminine elative as being phonemically /Pu?lā/, after the application of the regular development $\mathrm{Pv} \mathrm{V} C>$ ? $\overline{\mathrm{v}} \mathrm{C}$, as seen for example in *?a?kulu > ?ākulu 'I eat', *?u?tiya > Pütiya 'it was given'. With the loss of the initial hamzah, the second hamzah gets a chance to reappear, a phenomenon we mostly see in imperatives such as Pitti /(i)?ti/ but wa-Pti /wa-Pti/. The problem here, however, is that the interpretation of 'ū $l \bar{a}$ as /Pu?lā/, is clearly pseudocorrect due to the inherent ambiguity of the surface form. The root of this form is $\sqrt{\mathrm{i}} \mathrm{wl}$, and thus the underlying form is not ${ }^{* *} /$ ?u?lā/ but /Puwlā/.

\subsubsection{Durriyy $\rightarrow$ du/irrï?}

"a brilliant star" (Q24:35) is read by the majority of the readers as kawkabun durriyy, where the latter word is clearly to be understood as a denominal adjective of durr 'pearls' followed by the nisbah-ending. However, Pabu Samr and al-Kisāīi read this word as dirrî̀? and ŠuYbah Yan Yāṣim and Ḥamzah as durrï? (Ibn al-Ǧazarī, § 3731).

Ibn Xālawayh (huijjah, 262) explains that the reading dirrî̀? should be understood as an intensive adjective (like sikkit 'intensely silent') of the root $d r$ ? 'to avert; rush out (said of a torrent)', hence 'rushing out intensely' likening the rushing out to the intensity of the light. This explanation is probably a post hoc rationalization of a reading with a pseudocorrect hamzah. Ibn Xālawayh suggests that durrî? has the same meaning as dirrî?, but fuşill nouns like this otherwise do not exist in Arabic, so such an explanation is not particularly convincing.

\subsubsection{Måāyiš}

An interesting point where what is considered correct and what is transmitted comes into conflict is in the plural of ma ९̌šah 'livelihood', which in the reading 
traditions today is maSāyiš (Q7:10, Q15:20). The use of a $y \bar{a} ?$ in this case is surprising, other nouns with a similar structure consistently have a hamzah in this position, e.g. madīnah pl. madā?in 'town'; hadīqah pl. hadāîiq 'garden'; xalīfah pl. xalāiif 'successor'; qabīlah pl. qabäril 'tribe', etc.

The shift of $\bar{a} y i, \bar{a} w i$ to $\bar{a} i \bar{i}$ is essentially a regular development, and we find it not just in the broken plural pattern here, but also active participles of hollow roots, e.g. qã $\mathrm{rim}$ 'standing', and this development may also be the origin of word final $\bar{a}$ ? such as in samā? 'sky'?

The only place in Classical Arabic where both " $y$ and " $w$ are retained after $\bar{a}$ and before $i$ is in the verbal system, the L-stems retain the root consonant in the imperfective, even though the regular development would require a shift to $\bar{a}$ ?i. This, however, can be easily explained as the result of analogy. The perfective form regularly retains the root consonants, and this is simply expanded to the imperfect, where it would have regularly been lost. This development can be seen as a three-stage development as follows:

\section{$\begin{array}{lll}\text { 1. Proto-Arabic } & \text { 2. }{ }^{*} \bar{a} y i,{ }^{*} \bar{a} w i>\bar{a} P i & \text { 3. Analogical levelling }\end{array}$}

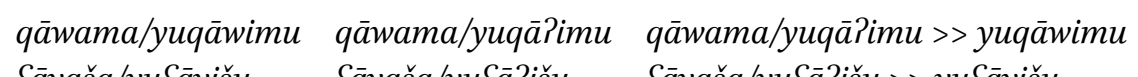
ৎāayaša/yuৎāyišu

For the plural maৎāyiš no analogical basis to which the " $y$ could be restored can be found. As such, maSāyis is a deviation from what we would expect a form of Arabic that underwent the ${ }^{*} \bar{a} y i,{ }^{*} \bar{a} w i>\bar{a} P i$ shift to produce. It turns out that in the reading traditions, the form maৎāis is in fact known. ${ }^{8}$ Ibn Muḡăhid, who does not usually spend time discussing ša $\bar{d} \underline{d}$ readings in his Sab $a$ ah fial-Qirā?āt discusses this form and is curt about it:

7 See Brockelmann $(1908,138 \mathrm{f}$.) for a discussion on this development, which has striking similarities with a development as found in Aramaic (see also van Putten 2020a, 61). Note however that this development cannot be reconstructed for Proto-Arabic, as varieties of Old Arabic still retain the glide in such places, e.g. Safaitic slmy /samāy/ 'sky', hyț /xāyeț/ 'travelling', gy' /gāyeS/ 'starving'. Moreover, the shift does not seem to have taken in several dialects of Yemen, where we find forms such as samāy 'sky', ?alhāy 'jaws' (pl. of liḥi) and famyāy 'blind' (cf. CAr.

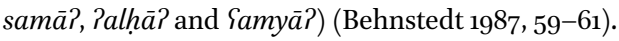

8 Vollers $(1906,95)$ takes the plural ma $\oint_{a}$ Piš as a pseudocorrection. Fück (1950, 39 f.), rather prescriptively, considers the reading ma ẫ?iš a mistake and evidence that there was a lack of a developed grammatical school in Medina. 
The word معيش: All of them read maৎāyiš without the hamzah. But Xāriğah, on the authority of Nāfi transmits maৎā? iš with an overlong vowel and a hamzah. And Pabū Bakr [ibn Muğāhid] said: this is a mistake. ${ }^{9}$

Sadly, Ibn Muğāhid does not elaborate on why he considers it a mistake. An answer is found in Sïbawayh's al-Kitäb however, who is in agreement with Ibn Muğāhid that this word should not have a hamzah. He argues that, because this word is derived from a root where the $y \bar{a} ?$ is part of the root $\sqrt{ } \xi y \check{s}$, this $y \bar{a} ?$ should be retained (Sïbawayh, IV, 354-357). Sỉbawayh is right to observe that this makes the word objectively different from the other words cited so far, where the $\bar{\iota}$ of the singular formation is part of the pattern CaCīCah, rather than part of the root, e.g. madinah has $\sqrt{\mathrm{mdn}^{10}}$ and țarīqah has $\sqrt{\text { țrq. }}$.

In this argument, Sibawayh is undoubtedly thinking of words such as the imperfective L-stem verbs such as yuৎāyišu where the root consonant is retained as well. However, we must conclude that this is a post hoc argumentation. First of all, we cannot assume that speakers of Arabic were themselves grammarians like Sïbawayh, and therefore a sound law that would only apply to CaCìCah nouns, when the $\bar{\imath}$ happened to not be the result of a root consonant, is not something that is likely to have occurred in natural language, as it requires a highly abstract model of formal grammatical thinking. Second, the argument that because the $y \bar{a} ?$ is part of the root it could not undergo the ${ }^{*} \bar{a} y i>\bar{a} i \mathrm{i}$ shift clearly breaks down in other derivational forms. The active participle of 'to live',

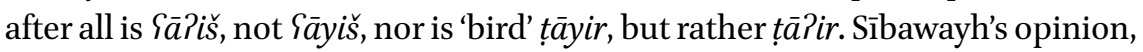
which Ibn Muğāhid upholds as the status quo, therefore cannot be seen as anything other than rationalization for his choice to prefer maSāyiš over maSāi iš when he was confronted with the choice between the two.

While later scholars of the qirā̃āt, such as Al-Dānī ( in line with Ibn Muğāhid's opinion, not all scholars found themselves in agreement with his judgment. Pabū Hayyān al-Andalusī (d. 754AH) in his al-Baḥr al-Muhit $(\mathrm{V}, 15)$ brings forth a rather spirited argument in favour of maSāisis as a correct and acceptable reading. ${ }^{11}$

9 qawluhū "معيش", kulluhum qara?a "maৎāyiša" bi-ġayri hamz. Wa-rawā Xāriğatu San

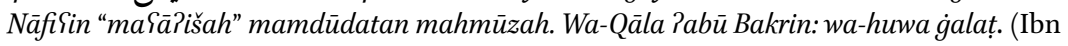
Muğāhid, 278).

10 Note that it is synchronically correct to consider this noun to be from a root $\sqrt{\mathrm{mdn}}$ in Arabic, as can also be seen from the other plural mudun, but ultimately in Aramaic, from

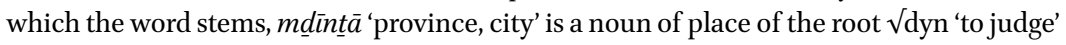
(Jeffery 2007, 260).

11 I thank Hythem Sidky for pointing me to this reference. 
The general public reads maৎāyiš with the $y \bar{a}$ ?, this is an analogy (qiyās), because the $y \bar{a}$ ? in the singular is part of the root, and not an extra letter to the pattern so that it receives a hamzah. When it is an extra letter of the pattern, they add the hamzah, for example sahâaitif of șahiffah. Al?aYrağ and Zayd b. Salī and al-?a@maš and Xāriğah, on the authority of Nāfí and Ibn Yāmir in their (respective) transmission read mąāi iš with a hamz. This is not analogy (qiyass), because they reported it, and they were trustworthy, so it is necessary to accept it (as a valid reading). This hamzah is irregular in the same way as it is irregular in manāirir, the plural of manārah-it is originally manwarah - and [it is irregular in the same way as it is irregular] in mașāiib, the plural of mașibah -it is originally mașwibah. Manāwir and mașāwib are analogies as they would say mașāwib on the basis of the root, in the same way that they say the plural of maqāmah as maquawwim; [the plural of] maSūnah as maSāwin.

Al-Zağğăğ said "all of the Basran grammarians decided that adding a hamzah is a mistake, but I know nothing of this perspective; [I know] only that [adding hamzah makes] it similar to șahĭfah, șahâarif and it is not proper to rely on this reading [i.e. maৎāisiš."

Al-Māzinī said: "The origin of the dispute of this reading is on the authority of Nāfị, but he did not know what the Sarabiyyah was, and the speech of the Arabs [i.e. correct Arabic] is to correct it [i.e. towards maৎāyiš] in such cases."

But we are not worshippers of the opinions of the grammarians of Basra! (lasnā mutaYabiddīna bi-?aqwāli nuḥāti l-bașrah).

Al-Farrā? said: "sometimes the Arabs added a hamzah to this and what is like it, supposing that it is a faYilah, and they liken maffilah to faYtlah" ${ }^{12}$ So, this is an account from al-Farrā? on the authority of the Arabs that they would sometimes add a hamzah to this and what is like it.

He brought an account of the reading of trustworthy people: Ibn Yāmir, he is a pure Arab, and he received the Quran from Suțān before corruption [of the Arabic language] manifested itself. As for al-?afrağ, he was among the greats of the readers of the followers [of the companions of the prophets]. Zayd $b$. Salī, with regard to eloquence and knowledge and cases one seldomly encounters, in that [more than] anyone. As for Al-?åmaš, he was, with regard to precision, perfection, memory and trustworthiness of high status. As for Nāfị, he was taught by 70 of the followers [of the 
companions of the prophet] and with regard to eloquence, precision and trustworthiness he was of high status, as he was not ignorant. Therefore, it is necessary that we accept what they relate to us, and [we should] not pay heed to the disagreement of the grammarians of Basra in this example.

As for the words of al-Mazānī "The origin of the dispute of this reading is on the authority of Nāfí", this is incorrect, because it is (also) reported on the authority of ibn Yāmir and on the authority of al-?a@rağ, Zayd b. Salī and al-PaImaš; As for the words "Nāfi did not know what the Sarabiyyah is", this is the evidence for the rebuttal: If we suppose that he did not know what the Sarabiyyah was; is it this skill [i.e. knowing what the Sarabiyyah is] which gives him access to speaking the language of the Arabs? He does not have to [know what the Sarabiyyah is] to do that [speaking the \{arabiyyah]! For he is eloquent of speaking the Sarabiyyah, as he is a transmitter of the reading on the authority of the eloquent Arabs. And many among those grammarians think badly of the readers, but it is not correct of them [to do] that.

This account clearly shows that, despite the objections of the Basran grammarians, such forms were known and at least allowed by some, and may have indeed been the regular outcome in the dialects that gave rise to the CaCâ?iC style plurals.

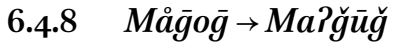

Yāșim is the only reader who reads the names of Gog and Magog as ya?ğūğ and maiğūğ, whereas the other readers read yāğūğ and $m \bar{a} \bar{g} \bar{u} \breve{g}$ (Ibn al-Ğazarī, $\S 1484)$. As these names are clearly borrowed from the Hebrew גוג ומגוג $g \circ \bar{g}$ $u$-mågog, which do not have a hamzah in either word, Yāșim's reading is an innovation from its original source.

\subsubsection{Zakariyya $\vec{a} \rightarrow$ Zakariyy $\bar{a}$ ?}

Most readers are in agreement that the Biblical name Zachariah in Arabic is supposed to end in a hamzah, i.e. zakariyya $\bar{a}$, this despite the fact that the Quranic rhyme in Q19:3 clearly suggests the name was pronounced /zakariyyā/ in Quranic Arabic. Only Ḥafș Yan Yāșim, al-Kisāîī, Ḥamzah and Xalaf lack this hamzah (Ibn al-Ğazarī, §2840). Considering that the Hebrew name is זכריה Zəkaryå, (or Greek Z $\alpha \chi \alpha$ pi $\alpha \varsigma$ ) without a final glottal stop, we must conclude that the majority of the readers are pronouncing the name with a pseudocorrect hamzah.13

13 Larcher (2021, 49, n. 40) suggests that the "Classical Arabic" form of this name has the 


\subsubsection{Sāq, sāqay-hā, sūq $\rightarrow$ sa?q, sa?qay-hā, su?q/su?ūq}

Another case of pseudocorrection is found in the plural and dual of $s \bar{a} q$ 'thigh, shank' in the canonical reading traditions. While in Classical Arabic this word is pronounced $s \bar{a} q$ pl. sūq, Ibn al-Ğazarī $(\S 3810)$ reports that Qunbul Yan Ibn Katîir read سوقه (Q38) بالسوق (Q:29) with a hamzah (= bi-s-su?q or alternatively bi-s-su?ūq), but his transmitter al-Bazzī read it without a hamzah. He also reports the presence of the hamzah for the dual ساقيه (Q27:44), i.e. sa?qay$h \bar{a}$ 'her two shins'.

Ibn Muğāhid (483) explicitly points out that the singular sāqin (Q68:42, and by extension presumably its other attestation in Q75:29) was not pronounced with a hamzah. Eventually the form without the hamzah wins out in the classical norm, and it is clear that even by Ibn Muḡanhid's time this was the norm, but it is also clear that the form with hamzah was a serious contender at least in the tradition that sprouted from Ibn Katîr. For the plural, the forms su?q and su'ūq have become canonical in Qunbul's transmission, rather than the expected form sūq.

Unease with these forms used by Ibn Katîr can also be gleaned in the discussion of Pabu Heyyān (VIII, 244 and also IX, 155), who quotes Pabū Yaliyy ${ }^{14}$ as saying that forms like $s a ? q$, sa?qay-hā and $s u ? q$ are weak, and that it is based on a 'well-known linguistic practice' (lugiah mašhürah) to apply the hamzah to a unvowelled $w \bar{a} w$ when a dammah precedes, citing a piece of poetry from Pabū Hibbah al-Numayrī: ?ahabbu l-mu?qidina Pilayya mu?sā 'Moses is the most beloved of kindlers ${ }^{15}$ to me.' This explanation fails to account for the presence of the hamzah in the dual sa?qay-hāa, and presumably for that reason Pabū Hayyān disagrees. He says that the form is acceptable because there is a hamzah in the root, clearly showing that as late as his lifetime there still had not

hamzah. This is a typical example of the imposition of modern norms onto the opinions of the Arab grammarians. Both Sībawayh (III, 394) and al-Farrā? (Luġāt, 47; Maৎānī, I, 208) explicitly state that this name may be pronounced Zakariyyā or Zakariyyā?u with no normative preference for one over the other. Incidentally, as there is no reason to consider Zakariyyā? $u$ as more original, it is of course incorrect to take its appearance in Q19:3 in rhyme as evidence that word-final $\bar{a}$ ? had lost its hamzah, in Quranic Arabic. It simply never had it, unlike the examples I adduce of $\bar{a}$ ? that does seem to rhyme with words that end in a final consonant, and are words that derive from ancient ${ }^{*} \bar{a} y$ sequences that shifted to $\bar{a}$ ? (van Putten 2018, 103-105).

14 Presumably Pabū Yaliyy al-Fārisī (d. $377 \mathrm{AH}$ ) a student of Ibn Muǧāhid (Ibn al-Ǧazarī al$\dot{g} \bar{a} y a h, \mathrm{I}, 189$ ). While Pabū Yaliyy discusses these variants in detail in his Huğğah (IV, 109111), nowhere does he call the hamzated forms weak.

15 In one of the two places that this line is cited, this form is vocalized al-mu?qidayni, but I would not know who these two kindlers would be. 
developed a complete consensus as to whether the root of $s \bar{a} q$ should be understood to be $\sqrt{\text { s?q }}$ or $\sqrt{\text { swq }}$.

The Arab grammarians were unable to resolve the question as to whether the root was supposed to contain a hamzah or not. But from a comparative linguistic perspective it is clear that the hamzah in the word is pseudocorrect. Other Semitic languages show no sign of the *? in this word. Aramaic has ša $q$, but the sequence ${ }^{*} a ? C$ should yield $\bar{e} C$ in Aramaic. This is clear from the verbal system, e.g. yemar 'he says' < "yaimuru and also from other words of the shape Ca?C, e.g. rēš 'head' (cf. Ar. ra?s, Hebr. roš spelled etymologically as ראש), kēb 'grief' (cf. Ar. kaib 'id.' and Hebr. kieb 'id.'). ${ }^{16}$ Hebrew has šoq, spelled שק; this points to the absence of the *? as Hebrew usually retains the spelling of the *? spelled with 'ål $\varepsilon \bar{p}$ in the consonantal text, but šoq is not spelled ** שאק. Finally, in Ugaritic, which retains the Proto-Semitic *? with a variety of signs, lacks it completely in this word $\langle$ šq $\rangle$ (not the expected ${ }^{* *}\left\langle\mathrm{~s}^{\prime} \mathrm{iq}\right\rangle$ ). This evidence leads us to an unambiguous reconstruction of this word for Proto-West Semitic as *s $s \bar{a} k$, without a glottal stop. The form $s \bar{a} q$ is therefore etymological and forms with a hamzah are pseudocorrect. ${ }^{17}$

On the discussion of $s \bar{a} q$, Ibn Xālawayh (Pi $i \bar{a} \bar{b}$, II, 152f.) explicitly calls out 'Arabs' for placing the hamzah in places where it is incorrect.

Others said: $s \bar{a} q$ is like $b \bar{a} b$, because the root is s-w-q, and the $w \bar{a} w$ is changed to an Palif, so it is incorrect to give it a hamzah. This is what is among the things in which the Arabs make mistakes, so they do apply the hamzah on what does not have a hamzah, and similarly with what has a hamzah they do not give it the hamzah, so ka?s and rais and sāq their stem shape (waznuh $\bar{a})$ is the same (i.e. as $C \bar{a} C$ ), so they make them similar to one-another, yes, he has seen that Arabs say: halla?tu s-sawiqa, but originally it is hallaytu, and likewise, with hallaitu l-Pinsāna Sani l-mā?i wa-l-Pibili. However, the plural of sāq, through replacement (qalb) (of the hamzah) is ?aswuq without hamzah and if you wish (can be) ?as?uq with hamzah.18

16 An interesting exception appears to be Aramaic $\Upsilon \bar{a} n \bar{a}$ 'sheep', which has lost the ? already

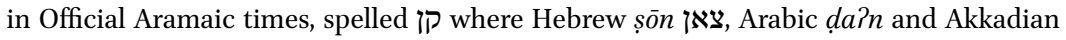
șēn point to a reconstruction *șa?n. This is probably the result of a dissimilation of the two guttural consonants occurring in a row.

17 As already recognized by Vollers (1906, 94). Vollers also noticed that such pseudocorrect forms entered the classical language through other channels than Quranic recitation, this is clear from the variable $b \bar{a} z / b a ? z$ 'falcon', which, considering that it comes from Persian $b \bar{a} z$, must certainly be considered a pseudocorrection as well.

18 This is the result of a fairly regular rule in the Sarabiyyah that sequences of ${ }^{*} w u$ or ${ }^{*} w \bar{u}$ 


\subsubsection{Kās $\rightarrow$ ka?s}

As already noticed by Blau $\left(1970,5^{6}\right)$, much like the case of $s a ? q$ discussed above, comparative Semitic evidence shows that ka?s 'cup' must have a pseudocorrect hamzah in Arabic. The reflexes in Hebrew כוס kos (spelled without 'ål $\varepsilon \bar{p})$ and Aramaic kās as well as Ugaritic $\langle$ ks $\rangle$ leave no doubt that the reconstruction of this noun in Proto-West Semitic is ${ }^{*} k \bar{a} t_{s}$ and the hamzah in the Quranic reading traditions must be pseudocorrect. What is different from the case of $s a ? q$, however, is that this word is read with hamzah universally by all the canonical readers. Moreover, this pronunciation has become the de facto standard in Classical Arabic, although the form $k a \bar{s}$ is known to exist among the lexicographers (Lane 2639c; Lisān 3802c).

\subsubsection{Yựāhūna $\rightarrow$ yuḍāhî̄ūna}

Yāṣim is unique in reading يضهون 'they imitate' (Q9:30) as a III-P root yudāhi?ū$n a$. All other readers treat the verb as a III-w/y verb, reading yuḍāhūna (Ibn al-Ǧazarī, §1532). This verb is attested in an Old Arabic inscription in Safaitic script as $d h w$ 'to copy' (Al-Jallad and Jaworska 2019). As Safaitic regularly retains the hamzah (Al-Jallad 2015, 45, 53), Sāșim's reading is evidently pseudocorrect here, and the majority reading is the original.

\subsubsection{Aṣ-ṣābūna $\rightarrow$ aṣ-ṣābîūna}

There is disagreement among the readers on how to read the Sabians' (Q2:62, Q5:69, Q22:17), which is variously read as aṣ-șābū/ina (NāfiY ${ }^{19}$ ) an $a s ̦$-șābi?ū/ina (the others) (Ibn al-Ǧazarī §1496). That is, either as an active participle from a root $\sqrt{s} b w / y$ or from a root $\sqrt{s} b$ ?

Neither the root $\sqrt{s} b w / y$ nor $\sqrt{s} b$ ? is attested in Arabic in a meaning that would elucidate the meaning of the word Sabians as an Arabic word; hence it is usually taken to be a loanword. If Wellhausen $(1897,237)$ is correct to identify this word as a plural active participle derived from the Mandaic verb $s \underline{b} \bar{a}$ 'to baptize' then we must conclude that the hamzah is a pseudocorrection. As the Mandaic form is a final weak verb, we would expect the plural active participle to simply be aṣ-șābūna. ${ }^{20}$

become $? u$, therefore the plural ?aswuq is expected to shift to ?as?uq. Note that this explanation is unable to make sense of the reading of the dual with hamzah, or in fact the other plural suî/suīù .

19 Pabū Ğaffar also reads $a s-s ̦ a \bar{a} b \bar{u} / \bar{\imath} n a$, but this is part of his regular pattern of dropping the hamzah (see section $\S 5.2$ ).

20 The Mandaic form is likely ultimately from a root ${ }^{*} s \dot{g}$ which yields Ar. șabaga to dye, baptize' and Aramaic șbaS with the typical loss of the gutturals of Mandaic. 


\subsubsection{Conclusion}

While the cases where hamzah is applied to a word which etymologically never had it is relatively rare, it is common enough to show that there was a real attempt to classicize the readings towards an ideal that included hamzah, by people to whom it was not necessarily obvious which words were supposed to have a hamzah or not. This is certainly consistent with what we would expect to find, considering that rhyme evidence shows that the Quran was originally composed in the Hijazi dialect without a hamzah.

It is remarkable that a good number of these pseudocorrections are found with Ibn Katîir, the Meccan reciter. Ibn Katiir, despite being a Hijazi, has a remarkably conservative use of hamzah in his recitation. Considering how the Hijazi vernacular appears to have mostly lost the hamzah, it is by no means surprising that it is exactly this reader that is most prone to pseudocorrection. It should be noted, however, that pseudocorrections are also found with other readers. All readers read $k a$ ?s, and the Kufans have several forms with pseudocorrect presence of hamzah as well.

\subsection{Failure to Insert hamzah}

While the amount of pseudocorrect insertions of hamzah in places where the word historically lacked the hamzah is a fairly rare occurrence among the readers, failure to insert the hamzah is more common. The tradition also explicitly acknowledges this: the dropping of hamzah is part of the Sarabiyyah (Sïbawayh, III, 541 ff.) and therefore grammarians did not see it as a problem to, in general, retain hamzah, but in cases that one was uncertain whether the root had a hamzah, to opt for the hamzahless form instead. However, the pseudocorrect application of hamzah was considered something to be avoided. This can be seen, for example in Pabū Yamr's statement concerning his reading of minsa?ata-hū as minsāta-hū (Ibn al-Ǧazarī, §3962). On this topic al-Farrā? (Maৎ̄ānī II, 356f.) reports:

Pabū JaYfar al-Ru?āsī (d. 187 AH) declared to me (al-Farrā?, d. 208AH) that he asked Pabū Yamr (d. 154AH) about it [i.e. the pronunciation of منستd], and (?abū Yamr) said: "minsāta-hū is without hamzah", and he also said: "Because I do not know it, I remove its hamzah."

A slightly more expanded version of this account is related by ?abu Ḥayyān (VIII, 531): 
Pabū Yamr said: "I do not apply hamza to it, because I do not know its derivation; If it was among those (roots) that are not hamzated, I have been (sufficiently) cautious (ihtattu), and if it was hamzated, then it would be permissible for me to take away the hamzah in what contains a hamzah."

This account clearly shows that the leaving out the hamzah in places where it is etymologically present was not considered a mistake, while adding it where it should have been was. Moreover, it shows that adding the hamzah was a rational and theoretical endeavour by the readers, and in case of uncertainty they could decide to leave it out.

The reading of Ibn Dakwān of this word is minsaita-hü (sic!). This is evidently ungrammatical as it suggests a miCCaCt stem formation, something that does not occur in any form of Arabic. It rather seems like an attempt at inserting the hamzah into a word that he originally learned to recite as minsāta-hü. If one disregards any forms of grammar, there is no way to decide whether a base for minsāta-hū is to be pronounced minsaita-hū or minsa?ata-hū.

Al-Dānī (Ğāmi extremely weak by the Arab grammarians in general, because the feminine ending should always be preceded by - $a$ - or an ?alif. But, he says, there is a line of poetry, transmitted by al-Paxfaš (the same person who transmits this reading for Ibn Dakwān), which serves as evidence that the form minsait- exists:

$x \times \cup-|x \times u-| x \times v-||$

șarî́u xamrin qāma min waka?ti-hī

'A drunk stood up from his reclination, like the standing up of an old man on his stick.'

The problem with this poetic evidence is that minsa?ti-hi is metrically identical to minsāti-hĭ, and therefore this poem can hardly be used as evidence for it. This is assuming that this line of poetry is not an outright fabrication, which seems more likely in this case. This anonymous line of poetry is only ever cited to explain Ibn Dakwān's reading, and al-Raxfaš seems to be the originator of the line.

The contemplative and theoretical nature of the reading with or without hamzah is also displayed in a colourful exchange between al-Kisā?ī and Hamzah on the discussion of al-Kisā?î reading $\underline{d i} i b$, as $\underline{\operatorname{d}} \bar{b}$ (Xalaf, Warš and regularly by his principles ?abū Ğaffar follow him in this exceptional reading, see Ibn al-Ğazarī § 1472). This is related in several Țabaqāt works, such as the one of al-Dahabī (153f.): 
[...] Muḥammad b. Salī b. Sulaymān al-Marwazī said: I asked Xalaf b. Hišām: why is al-Kisā?ī called al-Kisā?ī? And he said: al-Kisā?ī entered Kufa and came to the as-Sabîî mosque where Hamzah was teaching recitation, and al-Kisā?ī came forward and he was wrapped in a black robe. When Hamzah was done praying he said: who goes first? And it was said: "al-Kisā?ī", and they meant the guy in the (black) robe, and they turned their gaze to him and said: if you are a weaver, ${ }^{21}$ you will recite Sūrat Yūsuf and if you are a salt vendor (or sailor (?), mallāh), you will recite Sūrat Ṭāhā. So, he heard them and started to recite Sūrat Yūsuf, and when he arrived at the pericope of the wolf, he recited it without hamzah (i.e. $a \underline{d}-\underline{d} \bar{i} b$ ). So, Hamzah said: "ad-diib is with hamzah." So, alKisā?ī replied: "So should I apply the hamzah like that in al-hupt (for alhüt 'the whale') as well?" - this is about (the verses) fa-?akala-hu d-dirb (Q12:17) and fa-ltaqama-hu l-hüt (Q37:142). Hamzah looked to Xallād the cross-eyed, and they argued as a group, but nobody was able to (answer him). Then they said (to al-Kisā?ī): "liberate us, please!" Then (al-Kisā?ī) said: "Learn from what this weaver has to say! When you compare a man to a wolf, you say qad istada?abar-rağul 'the man was fierce like a wolf', and if you would say istadāba without hamzah, then it is as if you attribute to him emaciation $(h u z \bar{a} l)$ [because $\underline{d} \bar{a} b$ means 'vice, fault, defect']. But when you liken him to a whale, you say: istahāta r-rağul" - which means he eats a lot, because a whale eats a lot-and then he recited:

Payyuhā $\underline{d}$-dību wa-bnu-hū wa-?abü-hū

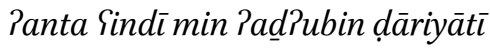

'O wolf, and his son, and his father!

You are to me among the voracious wolves!'

And he is known as al-Kisā?ī ever since that day.

This account once again shows that, while eliding the hamzah is considered acceptable - after all that is how the star of the story recites it - it is not allowed to pseudocorrectly apply the hamzah to words that do not have it in their root. ${ }^{22}$

\footnotetext{
21 Clearly meant as an insult, weavers were despised in medieval Islamic society, a position they share with the textor of Roman times ( $\mathrm{EI}^{2}$ s.v. $\left.h \bar{a}{ }^{2} i k\right)$.

22 Another humorous story about al-Kisā?î's reading of $\underline{d i} \hat{i} b$ as $\underline{d} \bar{l} b$ exploits the polysemy of the verb hamaza which means both 'to apply the hamzah' and 'to prod'. Someone asked al-

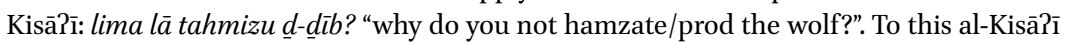
answers: ?axāfu ?an ya?kula-nī! "I am afraid that it would eat me!" (al-Dahabī, 300) where al-Kisā?îi is playfully riffing on the verse in which his reading $a \underline{d}-\mathbf{d} \bar{\imath} b$ occurs: wa-?axāfu ?an yarkulahu $\underline{d-d} \underline{d} \bar{b}$ "I fear that a wolf will eat him" (Q12:13).
} 
It is worth mentioning here a not quite as colourful, but related account on the authority of Nāif related by al-PașmaSī $\rightarrow$ Rabū SaSīd al-Ḥārițī $\rightarrow$ Ibn Muğāhid: "I asked Nāfí about الذيب and الذير, and he said: 'If the Arabs provide a hamzah to them, then provide them with a hamzah" (Ibn Muǧāhid, 346). This quote is related in the context of disagreement among the transmitters of NāfiY on these words. While most transmitters are in agreement that he read these words with hamzah, Warš and the non-canonical transmitter Ibn Ğammāz read them as al-bìr and $a \underline{d}-\underline{d} \bar{i} b$, a practice that Ibn Muḡāhid considered mistaken (wa-hā $\underline{d} \bar{a} w a h m)$. What this quote illustrates is the rather practical nature of reading with or without hamzah. Nāfi gives a rather non-committal answer to the question, telling the readers to follow what they believe what "the Arabs" do. ${ }^{23}$

Once we look closer among the canonical readers, we find numerous examples where there is uncertainty on whether a word is supposed to carry a hamzah or not, several readers opt for hamzah-less forms where according to their general principles of recitation we would expect them to have been retained. In the following section, we will examine the many cases of incomplete application of the hamzah as they occur among the readings.

All of this uncertainty about where the hamzah should go is difficult to understand, if we assume that the language of the Quran was indeed pronounced and transmitted with a hamzah from the very start. On the other hand, such discussions make perfect sense if the Quranic language was-as is admitted for Hijazi Arabic - without the hamzah, and as a new linguistic ideal of the classical poem gained prominence, reciters started adapting features, including the use of the hamzah, into their recitation.

\subsubsection{Long Vowels Followed by Hamzah \\ 6.5.1.1 Nabī?, nabīî̄īn, Panbîā?, nubū?ah}

The majority of the Quranic reciters do not pronounce the hamzah in the word

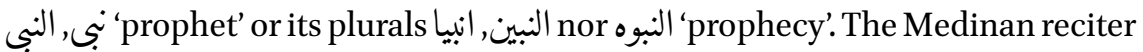
Nāfí, however is an exception to this, as he consistently recites these words as

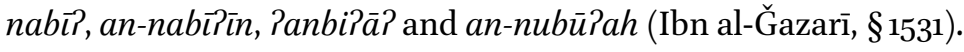

23 Ibn Muğăhid seems to have understood this quote as meaning that one is indeed to pronounce these words as $b i ? r$ and $\underline{d i}$ ? $b$, which reveals a significantly developed view of what 'Classical Arabic' is in the late third/early fourth century AH. To him what 'Arabs' say is clearly the form with hamzah. But one wonders if Nāfi truly meant it in such a manner. To Sỉbawayh, for example, $b \bar{i}$ and $\underline{d} \bar{i} b$ are acceptable and certainly also something that 'the Arabs' say (Sībawayh, III, 541ff.). 
This has frequently been construed as pseudocorrect application of the hamzah (e.g. Vollers 19o6, 95; Rabin 1951,131-133; Fischer 2002, 26), where Zwettler $(1978,179$ f., n. 71$)$ even claims that it was never part of the Sarabiyyah. From an etymological perspective it is not clear that this is correct. This word is ultimately a loanword from Aramaic or perhaps Hebrew, and while in later forms of both Aramaic and Hebrew the * $P$ is lost, Biblical Hebrew and Aramaic still retain the 'ål $\varepsilon \bar{p}$ spelling, suggesting its original presence and pronunciation in these respective corpora, cf. Biblical Aramaic Ktiv נביאה * נביאה

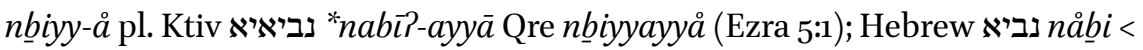

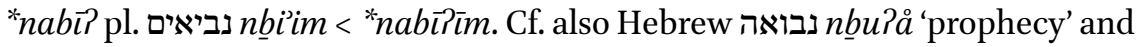
Biblical Aramaic Ktiv בנבואת חגי /*bi-nabū?at/ Qre bi-nóbu?at 'the prophecy of (Haggai)' (Ezra 6:14). As the Aramaic loanwords in the Quran consistently show exceptionally archaic phonology (see van Putten 2020a, $69 \mathrm{ff}$.), it is not a priori obvious that the presence of the hamzah in these words was never part of the Classical language.

The belief that this must be a pseudocorrection seems to be based on the fact that Sïbawayh (III, 555) expresses a clear normative bias against pronouncing the word as nabï? (and idem for barit?ah for bariyyah see the discussion below), saying that this is the manner of pronunciation of the people of the Hijaz who pronounce the hamzah, calling it rare and abhorrent (qalīl radî?). But while this is the case, he clearly considers the base of this word and baripah to contain a hamzah, as he discusses it as part of the shift of $\vec{\imath}, \bar{u} ?$, ay? $\rightarrow i y y, u w w$, ayy including words which in Classical Arabic are usually realized with the hamzah, e.g. $x a t \underline{\imath} \vec{\imath} a h \rightarrow x a t ̦ i y y a h$ 'sin', and maqrū? $\rightarrow$ maqruww 'readable'. For the formation of diminutives Sïbawayh (III, 547) explicitly allows both nubayy and nubayyi?, but the diminutives of barî?ah/bariyyah and nubü?ah/nubuwwah he only endorses the forms with hamzah, i.e. burayyi?ah and nubayyi?ah. So, while he has a normative opinion for the dropping of hamzah, he clearly considers the ?assl of the word to have had the hamzah. We cannot conclude from this that nabt? or bar$\vec{\imath}$ ?ah are pseudocorrect, but only that the now normative form without hamzah had gained enough ground in Basra in Sïbawayh's time that it was considered normative despite being exceptional among the people that usually preserve the hamzah. But Nāfi is Medinan and a contemporary of Sībawayh's teacher alXalil b. Rahmad, so clearly it was still part of the Sarabiyyah at that time despite Sībawayh's misgivings.

Despite the archaic nature of NāfiY's reading, it is quite clear that this was not the reading that belonged to the language of the QCT. The broken plural pattern the QCT uses (?aCCiCā?) is almost exclusively applied to final weak and geminate roots only a few sound roots have this pattern, e.g. $\dot{g} a n i y y \rightarrow ? a \dot{g}-$ niya $\bar{a}$ ? 'rich' and šadīd $\rightarrow$ ?ašidd $\bar{a}$ ? 'strong', qarīb $\rightarrow$ ?aqribāe 'relative' (van Putten 
2020a, 64). Had the Quranic Arabic form indeed been nab $\vec{\imath}$, we would have rather expected a plural nuba?āp?. ${ }^{24}$ This plural pattern therefore suggests that in Quranic Arabic, as would be expected in Hijazi Arabic the final hamzah had been lost and the word was indeed pronounced as the majority of the readers read it.

Nāfif's reading in this case is therefore an archaism, and one that was not considered proper by everyone. A commonly cited prophetic Hadith has some-

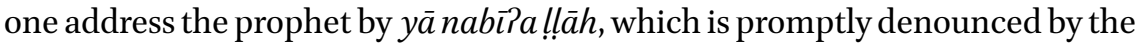
prophet. This tradition is explicitly invoked as one of the reasons why a reciter might read nabiyy instead of nab $\vec{\imath}$ by Ibn Xālawayh (Huğğah, 8of.): "the first reason is that applying the hamzah is heavy on their speech, and the evidence for this is his speech (PBUH): I am not the prophe' of God (lastu nabi?a lla ha ); it is as if he disliked applying the hamzah because he was of Qurayš who do not apply the hamzah".

\subsubsection{Barî2ah/bariyyah}

Another loanword from Aramaic or Hebrew is البريه 'creature' (Q98:6,7), which

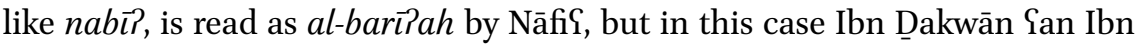
Yāmir joins him in this reading, other reciters read al-bariyyah (Ibn al-Ǧazarī, $\S 1536)$.

Here too we are likely dealing not with a pseudocorrection, but an accurate transmission of the ancient pronunciation of an original in Hebrew בריאה briaa and/or Aramaic (Jeffery 2007, 76), which is a derivation from the verb ברא 'to create' (Hebrew bårå), which likewise was borrowed into Arabic as bara?a.

\subsubsection{Nasî?}

(Q9:37) 'the postponement' is read by Warš San NāfiY (in the path of alPazraq) and Pabū Ğaffar as an-nasiyy while the other readers read it as an-nas $\vec{\imath}$ ? (Ibn al-Ǧazarī § 1525). In the context, it seems quite clear that we should derive this word from the root nasa?a 'to postpone; to drive', and not from nasā 'to forget', where an-nasiyy would end up meaning 'the forgotten one; that which is to be forgotten'. Note that minsa?ah, also a word derived from this root, likewise yielded uncertainty among the readers as to whether or not it should have the hamzah (see $\S 6.5$ above).

24 This plural is in fact attested in a poem by al-Sabbās b. Mirdās (d. ca.18-35AH) starting with yā xātama n-nuba?ā? Pinnaka mursalun "O seal of the prophets, you are sent" (al-Ǧabbūrī 1968, 95), another piece of evidence that the form nab $\vec{\imath}$ pl. nuba? $\bar{a} ?$ indeed existed in the Sarabiyyah, also outside of Quranic recitation. 
Ibn Muǧahid (314) reports several other readings. In non-canonical transmission paths of Ibn Katiir we find an-nas? (Guqayl $\leftarrow$ Šibl $\leftarrow$ Ibn Katīir)—a reading that seems to disagree with the rasm -and an-nasiyy (Gubayd $\leftarrow$ Šibl $\leftarrow$ Ibn Katîr). He also reports an-nasy on Ibn Katīir's authority, but without Pis$n \bar{a} d$.

\subsubsection{Xațî̉ah pl. xațāyā 'sin'}

A clear example of failure to apply hamzah in the QCT which has subsequently made it into the Classical Arabic language is the plural formation of $x a t \underline{\imath} \vec{\imath} a h$ 'sin', its plural, xatāy $\bar{a}$, not only lacks the expected hamzah altogether, it could never have even had this hamzah, as the plural formation it employs is one typical of final-weak roots. Fischer $(2002, \S 99 \mathrm{~b})$ cites as examples hadiyyah pl. hadāyā 'gift', hirāwah pl. harāwwa 'club' and zāwiyah pl. zawāyā 'corner, angle'.

There are some other contexts in which the CaCāCā plural appears, but none of them apply to $x a t \underline{\imath} \vec{i} a h^{25}$ There are a few isolated lexical items that take this plural of sound roots, for example yatīm pl. yatāmā. Note, however, that if $x a t \underline{\imath} \vec{T} a h$ would belong to this group of nouns we would have expected **xațā? $\bar{a}$ rather than the inexplicable $x a t \bar{a} y \bar{a}$.

As such we would expect the original singular of this noun in Quranic Arabic to have been the hamzahless form xatiyyah, following the same derivation as hadiyyah. The reading xațiyyah was subsequently classicized to $x a t ̦ i \vec{\imath} a h$ by all readers, while failing to classicize the plural formation along with it. ${ }^{26}$ The issue of this specific broken plural pattern associated with this singular was not lost on the Arab grammarians, and Lisān al-Sarab has a lengthy discussion on what was evidently perceived as a problematic plural. The regular plural of CaCīCah nouns is CaCāPiC (cf. hadīqah pl. hadāPiq; madīnah pl. madāPin), and as such the expected plural is al-xațāii? ${ }^{27}$ due to the regular elision of the second hamzah when two hamzahs follow in a row, this should have become $a l-x a t \bar{a} \bar{\imath} \bar{l}$, in the same way that the active participle of 'to come' turns from al-

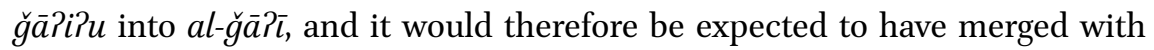
the fasālin type plurals. Sībawayh (III, 552 f.) starts his discussion of this plural

25 For example, it is a regular plural (besides CaCāCin) for nouns that end in the feminine endings $-\bar{a}$ and $-\bar{a}$ ?, e.g. fatwā 'legal opinion', pl. fatāwin, fatāwā and $\mathcal{S} a \underline{d} r \bar{a}$ ? 'virgin' pl. Sadāarin, Yad̄ārā (Fischer 2002, §99a).

26 The expected for xațiyyah is attested in Classical Arabic lexicons (Lane 761c; Lisān 1193b).

27 Al-Zamaxšarī (mufașsal, 167) cites Pabū Zayd as having heard someone use this original

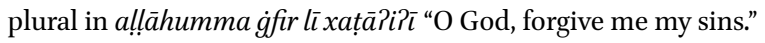


with: "it is as if [the hamzah] was turned into a $y \bar{a}$ ? and the end of $x a t \bar{a} \bar{a} \bar{a}$ (i.e. the $y \bar{a}$ ? of $x a t \bar{a} \bar{a} \bar{l}$ ) was replaced with an ?alif". He then commences to explain how one could get from a singular $x a t \underline{i} \vec{\imath} a h$ to the plural $x a t a \bar{a} y \bar{a}$ without having to assume a singular base xatiyyah. He likens the replacement of the final $y \bar{a}$ ? of

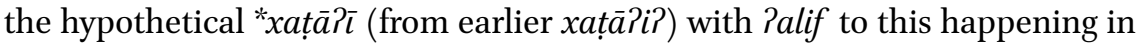
the final weak plural mațaya (plural of mațiyyah 'mount'), it is striking here that Sỉbawayh has to draw an analogy with a CaCiyyah noun, to be able to explain the presence of this plural pattern, while the discussion seems explicitly aimed to avoid this. This brings him to an intermediary form "xațā? of " $x a t \bar{a} \bar{\imath} \bar{a}$ is subsequently replaced with a $y \bar{a}$ ? because it stands between two Palifs. While hamzah as a root consonant can stand between two ?alifs such as

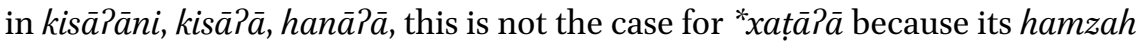
is not a root consonant, but part of the plural pattern (CaCā?iC), therefore it is weakened to a y $\bar{a}$ ? instead, yielding $x a t a \bar{a} y \bar{a}$. The change from $\bar{\imath} \rightarrow \bar{a}$ is, of course, $a d h o c$, as is the rule for replacing the hamzah with a $y \bar{a} ?$ to go from $x a t \bar{a} ? \bar{a}$ to $x a t \bar{a} y \bar{a}$, which as far as I can tell is not applied to any other word in the lexicon.

The complexity of discussion ultimately comes down to the fact that Sïbawayh, and grammarians after him (see the discussions in Lisān, 1193, for example) refuse to use a surface form like xatiyyah - a form explicitly considered to be allowed - for the derivation of the plural. This constraint that the grammarians imposed upon themselves does not lead to a convincing explanation, and that does not seem to have been the point. The grammarians were simply trying to find an explanation of how one could hypothetically come from the idealized source form $x a t ̦ i \vec{\imath} a h$ to $x a t \bar{a} y \bar{a}$ without having to assume the loss of hamzah as the basis. The self-evident explanation for the plural $x a t \bar{a} y \bar{a}$ is that it was formed upon the form xatiyyah, not xațī?ah, thus betraying an original hamzahless form, despite its absence in the canonical readings.

\subsubsection{Post-consonantal Hamzah}

Above, we discussed a class of words with the lack of the expected hamzah when it occurs after a long vowel. But this is not the only position where we find that readers irregularly lose the hamzah. We also find it in post-consonantal position.

The very name of the Quran itself is one of these cases where the presence of the hamzah is disagreed upon. The word is spelled both defectively and plene قران in early manuscripts, and it is usually read as quriān, however Ibn Katīir reads it as qurān (Ibn al-Ğazari, §1571). There can be no doubt that the root of qur?ān 'recital' is qara?a 'to recite', and thus in qurān the expected 
hamzah is missing. Attempts of Arab philologers to see Ibn Katīir's qurān as a derivation from qarana 'to bring together' are obviously not very satisfying (Jeffery 2007, 233).

Nāif treats two CiCC verbal nouns derived from III-? roots as CiC stems, 12, ridan (versus the other readers ridian) 'as help' (Q28:34; Ibn al-Ğazarī, §1559) and ل milu 'fullness' (Q3:91; Ibn al-Ǧazarī, §156o, only in the path of al-Raşbahānī from Warš, and with disagreement among his transmitters). Thus here, like our previous word, post-consonantal hamzah was incompletely reinserted in this reading.

The QCT of the Quran makes it clear that there was no hamzah in the imperative sa?ala 'to ask', as it is consistently spelled سل Had this word had a medial hamzah, we would have expected a prothetic ?alif in the imperative ** اسل for is?al. As such, to agree with the rasm, readers have to read sal if nothing is prefixed to the word. However, whenever $w a$ - or $f a$ - precede the imperative, readers generally include the hamza, as now the rasm allows the correct syllable structure, hence: wa-s?al al-qaryah 'ask the village' (Q12:82) and fa-s?alü Pahla d-dikr 'ask the people of remembrance' (Q16:43). Ibn Katîir, al-Kisāīi and Xalaf, however, always read the hamzahless form regardless of context (Ibn alĞazari, §1562). Either reading is, of course, irregular as the imperfect forms of this verb have the same phonetic context but are invariably read as yas?alu etc.

There are several words that are expected to have a post-consonantal ham$z a h$ on comparative grounds, but where all readers are in agreement to not read the hamzah. The most obvious of these is the word oك malak 'angel'. This word is generally taken to be a loanword from Gəโəz măliăk pl. mălarəkt 'id.,' mostly because it shares the same plural formation as the Arabic مليك malärikah, which is a plural formation that is rare, and mostly restricted to loanwords (van Putten 2020a, 66). The Gə९əz form itself is, of course ultimately derived from the Hebrew מלאך mal'åk 'id.' or Aramaic mal'akāa 'id.'

The Arabic plural itself clearly points to a missing postconsonantal hamzah; there are no other $\mathrm{CaCaC}$ nouns that have such a quadriradical plural formation (or more common formations like CaCā?iC). The lexicographical tradition does in fact record the expected form maliak (Lisān $426 \mathrm{gb}$ ), but the canonical readers are in agreement that the form is malak, despite this being an irregular outcome within the phonologies of these reading traditions.

The imperfect of the verb $r a ? \bar{a}$ forms a surprising exception to the retention of postconsonantal hamzah, as it is not yariā but yarā/yarē among all the canonical readers. The irregular behaviour of this verb seems to have already been a feature of the Sarabiyyah by the time of Sibawayh (III, 546), as he explicitly mentions the exceptional nature of this word: "all Arabs agree on the dropping of it (the hamzah in forms like ?arā, tarā, yarā, narā) because of its 
frequent use", but he adds: "Rabū al-Xațāab told me that he has heard one say qad ?ar?ā-hum bringing the verb in its original form ra?aytu, among the trustworthy Arabs." Al-Farrā? (Luġät, 165) also says that all Arabs agree on dropping the hamzah with the exception of the Banū Pasad and Taym al-Rabāb. ${ }^{28}$

\subsubsection{Intervocalic Hamzah}

6.5.3.1 Rîā?a n-nās $\rightarrow$ riyāâa n-nās

ريا الناس 'to be seen by men' (Q2:264; Q4:38; Q8:47) is read by most readers as

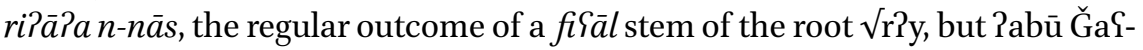
far has irregularly shifted the medial hamzah to yā? , yielding riȳâ?a n-nās (Ibn al-Ǧazarī § 149o). ${ }^{29}$

\subsubsection{Li?allā $\rightarrow$ liyallā}

Warš Yan Nāfi in the path of al-Pazraq reads ليلا as liyallā 'so that not' (Q2:150; Q4:165; Q57:29), while the rest of the Quranic readers read li-Palla (Ibn alĞazarī, §1495). This is irregular behaviour in the reading of Warš, which otherwise retains the hamzah in such environments.

\subsubsection{Kufu?an, huzu?an $\rightarrow$ kufuwan, huzuwan}

While Hafș is generally very conservative in the retention of the hamzah, he is unique in dropping the hamzah in كفو ' كزوا 'contempt', reading them as kufuwan and huzuwan respectively, while the other readers read these words either as kufu?an/huzu?an (the majority reading) or kuf?an/huz?an (Hamzah) (Ibn al-Ğazarī § 2668).

\subsubsection{Bādiya r-ra?yi $\rightarrow$ bādi?a r-ra?yi}

An interesting point of disagreement among the readers on the placement of the hamzah occurs in the phrase بادى الراى (Q11:27). The majority of the readers reads بادى الراى as bädiya r-raßyi, only Pabū famr reads it with hamzah,

28 A few early manuscripts appear to give evidence that in earlier times such readings were more widespread. The vocalization of Arabe 334a's يروا (Q36:31), places a fathah sign on the $r \bar{a}$ ? which likely denotes the presence of a hamzah, thus suggesting yar?aw, and the spelling يراى DAM 01.29-1 leaves little doubt the scribe intended yar?ā/yar?ēe, as this manuscript frequently employs the ?alif to denote the presence of hamzah (van Putten 2019a, 370, n. 210).

29 This should not be considered part of the dissimilation of two consecutive hamzahs as in *PaPimmah > Payimmah 'Imāms' and *ăă (2002, § 41a). The dissimilation, at least as described by Sībawayh (III, 552) is always progressive, not regressive, and only occurs if a short vowel intervenes. 
i.e. bādiła r-raßyi (Ibn al-Ǧazarī, § 1535). However, it is not entirely clear that we are dealing with a pseudocorrection or irregular absence of hamzah.

Ibn Xālawayh (Huğǧah, 186) takes Pabū Yamr's reading as primary, saying that whoever reads it as badiya is deriving it from the verb bada?a/yabda?u 'to begin' and is dropping the hamzah thus understanding the phrase as "beginning in opinion". If this interpretation is correct, we are indeed dealing with the absence of the expected hamzah which is irregular among each of the readers that reads it thus.

However, al-Farrā? (Maৎānī, II, 11) clearly has a different opinion and views $b \bar{a} d i y a$ and $b \bar{a}$ di? $a$ as two separate lexical items. He tells us: "you should not apply the hamzah to bādiya, because the meaning yabdū 'it is obvious' seems more obvious to us [i.e. "obvious in opinion"]; if you were to apply the hamzah to it, then you would intend the meaning ?awwal al-ra?y "first/beginning in opinion." " If al-Farrā? is correct to see the two readings as intending two different meanings, this obviously still stems from an ambiguity of the text which only became ambiguous when readers started to add the hamzah to the recitation of the Quran.

\subsubsection{Pre-consonantal Hamzah}

Among the canonical readers, the dropping of hamzah in pre-consonantal position is by far the most common, because it is a regular practice in a restricted form with Warš, and mostly unrestricted for Pabū Ğaffar and Pabū Samr (optional for the latter). For the other readers, however, such dropping of the hamzah is not regular, but despite that, it is occasionally attested in isolated words among the other canonical readers.

At the start of this section (§6.5) we already mentioned that al-Kisā?ì read $a \underline{d}-\underline{d} \bar{i} b$ 'the wolf' without hamzah. Xalaf joins him in this reading. Warš likewise drops the hamzah in this word, but adds to it also bir 'well', and bisa, bisa$m \bar{a}$ 'how bad!' (Ibn al-Ğazarī §1471-1472). Also, the reduplicated noun lu?lu?, ŠuSbah Yan Yāșim goes against his general principles reads lülu? in all its attestations (Ibn al-Ǧazarī §1482). Qālūn Yan Nāfi and Ibn Dakwān Yan Ibn Yāmir read ريا (Q19:74) as riyyan rather than riłyan (Ibn al-Ǧazarī §1483). Finally, Qālūn Yan Nāifi, with disagreement among his transmitters, reads al-mütafikah (Q53:53) and al-mütafikāt (Q9:70; Q69:9) 'that which is overthrown', rather than mu?tafikah/mu?tafikāt (Ibn al-Ǧazarī §1482).

التين 'the fig' (Q95:1) is an example where all readers are in agreement that the word is to be read as at-tin, without hamzah, whereas from an etymological perspective, it seems that this word should have had a hamzah. Hebrew

30 The pronunciation $t$ ? enå of the Tiberian reading tradition is likely also pseudocorrect, as the glottal stop is expected to have been lost here. 
and Syriac $\ll \phi \kappa \phi t e t t a \overline{~ b o t h ~ p o i n t ~ t o ~ a ~ r e c o n s t r u c t i o n ~ * t i ? n-(a t-), ~ w h i c h ~ w o u l d ~}$ be expected to just yield ti?n in varieties that retained *?

The suppletive imperative hātū 'give!' lacks a hamzah among all readers where it would be expected to exist. The verb is transparently historically derived from an imperative of the $\mathrm{C}$-stem of $\sqrt{ }$ ity, i.e. ? $\bar{a} t \bar{a}$ 'to give', and it still inflects as an imperative of this type in Classical Arabic hāti (m.sg.); $h \bar{a} t \bar{\imath}$ (f.sg.); hātiya (du.); hātū (m.pl.); hātīna (f.pl.). In the Quran only the masculine plural $h \bar{a} t \bar{u}$ is attested (Q2:111; Q21:24; Q27:64; Q28:75).

The initial $h$ is an ancient retention of the Central Semitic C-stem, which had an $* h$ - as can be seen, for example in the Hebrew C-stem that has the shape hip̄ $\{e l$. So, where the causative in Classical Arabic is expected to be Pāti< * $P a ? t i$, the form $h a \bar{t} i$ developed from a form with retained ${ }^{*} h$, i.e. * $h a ? t i{ }^{31}$ While Classical Arabic undergoes a dissimilatory process of $* ? v ?>i \bar{v}$ that can explain the lack of the glottal stop in the regular imperative ?âti, this same sound law cannot be used to explain the absence of the glottal stop in hâti, which has irregularly lost the hamzah in Classical Arabic as well as all reading traditions. This form probably developed because the form $h \bar{a} t(i)$ was not transparently analysable to the speakers anymore as coming from the root $\sqrt{ }$ tty, and thus the hamzah could not be reinstated.

\subsubsection{Interchange between III-w/y and III-P Verbs}

In most, if not all, modern Arabic dialects, III- $w / y$ and III-? merge completely. This merger is already well on its way in the language of the QCT. In the imperfect, the verbs appear to have been indistinguishable from final weak verbs, and in the imperative and jussive, etymological III-? verbs behave as III- $y$ verbs three of the seven times they occur (see Appendix A.4.13). The result of this partial merger has also led to disagreement between the readers as to whether a verb form should be treated as a III-? or a III- $y$ verb.

Most conspicuous of the verbs that show this disagreement is the verb ?ar$\check{g} a$ ?a/Parg $\bar{a}$ 'to postpone' forms of which occur throughout the Quran, with clear disagreement between the readers (Ibn al-Ğazarī, § 1229; § 1533).

31 For an account of the development of the C-stem from ${ }^{*} s^{l}$ to ${ }^{*} h$ and ultimately to ? in Arabic, see Al-Jallad (yusap $i l$ ). Al-Jallad argues that ${ }^{*}{ }^{I}$ regularly becomes $h$ on wordboundaries in Proto-Central Semitic. For Arabic, ${ }^{*} h$ becomes $?$ in pre-stress position, thus explaining the shift of *him 'if' and *hinna 'verily' to Pin and Pinna. He moreover argues that *hafiala $>$ ?afiala is the result of the same sound shift, drawing upon stress marking in the Damascus Psalm fragment to argue that the stress of C-stems was *?afiála in Proto-Arabic, something that would be corroborated by Hebrew which likewise carries the stress in this position. If this is correct, it would seem that the imperative form of the verb of *ha?ti carried the stress on the penultimate, i.e. *há?ti, which would explain the retention of the ${ }^{*} h$ in this position. 


\begin{tabular}{|c|c|c|c|c|c|c|c|}
\hline & $\begin{array}{ccc}\text { IK } & \text { IA } \\
& \text { H }\end{array}$ & AA Y & $\begin{array}{l}\text { IA } \\
\text { ID }\end{array}$ & $\begin{array}{ll}\text { N } & \text { AJ } \\
\text { Q } & \text { IW }\end{array}$ & $\begin{array}{llll}\mathbf{N} & \text { AJ } & \text { K } & \mathbf{X} \\
\mathbf{W} & \text { IJ } & & \end{array}$ & $\begin{array}{ll}\text { H } & \mathbf{A} \\
& \text { Họ }\end{array}$ & $\begin{array}{l}\text { A } \\
\check{S}\end{array}$ \\
\hline (Q7:111; Q26:36) ارجه (Q) & Parğì-hū & Parğî-hu & Parğî?-hi & Parği-hi & Parği-hī & & Parği-h \\
\hline (Q9:106) مرجون (Q) & \multicolumn{3}{|c|}{ murǧa?ūna } & \multicolumn{3}{|c|}{ murğawna } & murğa?̄ūna \\
\hline (Q33:51) ترجى & \multicolumn{3}{|c|}{ turǧi?u } & \multicolumn{3}{|c|}{ turğì } & turǧi?u \\
\hline
\end{tabular}

Leaving the unusual treatment of the pronominal suffix of ارجه aside for now (for a discussion on that see $\S$ 7.1.8), there is a mostly regular split: The Damascene, Meccan and Basran readers treat the verb as a III- $?$ root, whereas the Medinans and Kufans treat it as a III-y root, with the exception of ŠuSbah San Yāsim who has a mixed paradigm where the imperative is III- $y$ and the other forms III-P. As I have found no cognates of this verb in other Semitic languages, it is difficult to be sure whether the form with the hamzah is the original form, or a pseudocorrection.

Another verb that shows disagreement between the readers are derivations from wațiia 'to tread, step on'. Pabū Ğaffar in accordance with a general rule of his reads يواطوا (Q9:37) as yuwāțū rather than yuwāții the forms of the G-stem يطون (Q9:120), تطوها (Q33:27), تطوهم (Q48:25) he reads as yatawna, tataw-hā and tataw-humu respectively, where the other readers

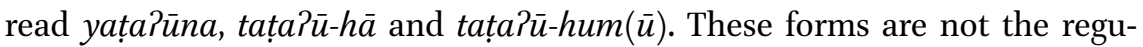
lar outcome of his general hamzah loss rules. Other verbs of this type simply retain the hamzah, e.g. يقرون (Q10:94; Q17:71) as yaqraiūna. He also reads موطيا 'step' (Q9:120) as mawțiyan rather than mawțian. Pabū Ğaffar is inconsistent on the treatment of this sequence, cf. سييا خاسيا xaysiya (Q67:4).

However, he treats وطا 'impression' (Q73:6) as a III-? stem, reading waț?an. This is rather surprising as wițâpan is also consistent with the rasm and would have matched the treatment of this root as both III- $y$ and III-P, and this is in fact how Pabū Yamr and Ibn Yāmir read (Ibn al-Ǧazarī, § 4467).

\subsubsection{Säla for sa?ala (Q70:1)}

Nāfif, Rabū Ğaffar and Ibn Yāmir read wlin Q7o:1 (and only there) as sāla, with the expected hamzah not reinstated, which they do have elsewhere in their reading. Thus, for both of them سالك is read as sa?ala-ka in Q2:186, for example (Ibn al-Ǧazarī, § 4441). 


\subsection{7 Šurakā-ya (Q16:27) for al-Bazzī Yan Ibn Kațīr}

Most readers are in agreement that شركى (Q16:27) should be read with hamzah, šurakā?-iya 'my partners', but al-Bazzī Yan Ibn Katīir (with disagreement among his transmitters) reads it as šurakā-ya, treating this plural as a ?alif maqșürah rather than an Palif mamdūdah (according to Ibn Muğāhid, 371, and al-Dānī altaysirr, 137, but not according to Ibn al-Ğazarī, §3417). This is not the regular behaviour of al-Bazzī with this noun. In fact, even the other cases of the phrase شركاى 'my partners' (Q18:52; Q28:62, 74; Q41:47) are read by al-Bazzī as šurakā?iya.

\subsection{Conclusion}

In the above sections we have examined the position of the hamzah among the canonical readers. As is clear from this discussion we can find ample examples both of the application of hamzah where it is evidently pseudocorrect and places where the reading traditions lack hamzah where their regular rules would not predict it. These findings show that Blau's assertion that there is no trace of pseudocorrection in the Quran is incorrect. Besides a good number of pseudocorrect hamzahs, we also find many examples where the readers fail to insert the hamzah where we would expect it. This combined with reports of introduction of hamzah in the second century (at least in Medina) suggests that application of the hamzah into the text was part of the goals of the Quranic readers. These readers would not always have the means to do this correctly, sometimes overzealously applied it to words that certainly never had it, and in other cases refrained due to uncertainty.

Of course, this does not show that the language was composed without hamzah, that evidence can only be retrieved from Quranic rhyme and orthography. What it does show is that the Quranic reading traditions cannot be taken as a reliable guide for the language of the Quran in this regard. The readers were actively trying to apply hamzah in what they considered to be the correct way (mistaken or not), and there is no indication that these attempts had anything to do with what the situation was in the original composition. As such, the presence and pervasive use of hamzah in the Quranic reading traditions cannot inform us as to what the treatment of the hamzah in the original language of the Quran was. 